\title{
Population Dynamics of the Striped Mealy Bug Ferrisia virgata (Cockerell) (Hemiptera, Pseudococcidae) and the Scope of its Biological Suppression in the Present Scenario of Cultivation of Indian Sandalwood
}

\author{
Rashmi R Shanbhag ${ }^{1 *}$ and R Sundararaj ${ }^{2}$ \\ ${ }^{1}$ Biology Division. Indian Plywood Industries Research and Training Institute, Institute of Wood Science and Technology, India \\ ${ }^{2}$ Division of Forest and Wood Protection, Institute of Wood Science and Technology, India
}

Submission: February 01, 2017; Published: August 30, 2017

"Corresponding author: Rashmi R Shanbhag, Division of Forest and Wood Protection, Institute of Wood Science and Technology, $18^{\text {th }}$ cross, Malleshwaram, Bangalore-560003, India, Email: rashmishanbhags@gmail.com

\begin{abstract}
Organically grown sandalwood (Santalum album Linn.) is the need of the market hence the insect pest control need to be done using organic materials or natural enemies. The striped mealy bug Ferrisia virgata is turned as one of the major sandalwood pests due to its inter-cultivation with horticultural crops. A study was conducted to investigate the population dynamics of $F$ virgata infesting sandalwood in Bangalore, India and the probability of its control by using the Australian ladybird beetle Cryptolaemus montrouzieri. For this purpose population data collected was correlated with the meteorological data viz., monthly mean maximum and minimum temperatures, morning and evening relative humidity and total rainfall during the experimental period. Minimum temperature $(\mathrm{r}=0.616)$, maximum temperature $(\mathrm{r}=0.634)$ and rain fall $(\mathrm{r}=0.383)$ asserted significant positive correlations whereas maximum $(\mathrm{r}=-0.233)$ and minimum relative humidity $(\mathrm{r}=-0.579)$ showed negative correlation with the Fvirgata population. Biological control experiments showed that $C$. montrouzieri could control $F$. virgata within two months of its release. In the light of these findings the scope of its biological suppression in the present scenario of cultivation of Indian sandalwood is discussed.
\end{abstract}

Keywords: Santalum album L; Ferrisia virgata; Weather parameters; Cryptolaemus montrouzieri

\section{Introduction}

Agroforestry systems are not new to India; traditionally each and every Indian locality has its own types of indigenous agroforestry systems [1]. In fact India has around 24,602 million trees outside forests [2] spread over an equivalent area of 17 million ha (National Forestry Action Programme, Government of India, Ministry of Environment and Forests, 1999) [3]. National Agriculture Policy (2000) emphasized the role of agroforestry thus putting lots of inputs into agroforestry research and agroforestry plantation establishments as future depends on this. Support of government to establish plantation resulted in the establishment of many commercial plantations.

Indian sandalwood is on of such commercial species with sure returns to the grower. But until 2008 especially in Karnataka government had monopoly on sandalwood cultivation, harvesting and selling. Even the ownership right of naturally grown sandalwood tree in private land also belonged to government as it was termed as nationalized tree. A farmer was supposed to inform the authorities regarding tree but farmer will remains responsible for the care of the tree. If there is a theft or a tree dies the farmer is expected to report the matter and is usually considered the prime suspect. And when the government decides to fell it, the farmer gets 75 per cent of a price determined by the forest department which can be one-fourth of the market price and that too after a long delay. All that changed in 11th July 2008 when government issued notification with further amendment in laws 2001 and 2002 which gave ownership and selling rights to private owners and institutions [4]. This has generated interest in public and private sectors to raise sandalwood plantations and a large number of farmers and individuals with large land holdings have have taken up commercial plantation of sandalwood in Karnataka, Maharashtra, Andhra Pradesh and Rajasthan considering its economic benefits [5]. 
Indian Sandalwood is not only a "Royal Tree" of Indian subcontinent also a symbol of Indian culture and heritage. Even the economic importance sandalwood tree is well documented and as of know it is the second most expensive wood in the world [6]. Scented heartwood of sandalwood tree yields essential oil which alone contributes to the revenue of around Rs. 160 million through the export of almost 27 tons of oil per year. Annual world markets demand of sandalwood is around $5000-6000$ tons of which more than two-third is for Indian sandalwood [7]. A large gap between demand and supply existing as currently output of sandalwood in country due to declining productivity and quality [8] as a result market prices of sandalwood and oil have increased to the level of Rs.1.2 millions per ton and Rs.75000 per kilogram, respectively. As per Karnataka Government outlet (2012) cost of $5 \mathrm{~g}$ of oil is Rs.1500, which works out to be Rs 300,000/kg [6].

This prospective economic resource of country is not devoid of diseases and pests, among the various factors, insect pests are one of the most important factors limiting the successful establishment of sandalwood plantations [7]. Insect pest attacks on sandalwood will get aggravated when it is grown in agro-horticulture forestry systems as pests of other species are showing shift to the sandalwood. As of know Indian farmers are growing sandalwood along with other horticultural, commercial other trees like Tectona grandis, Grevillea robusta, Azadirachta indica, Tamarindus indica, Melia dubia, Anacardium occidentale, Areca catechu, Cocos nucifera, Phyllanthus emblica, Moringa oleifera, Citrus reticulate, Mangifera indica, Psidium guajava, Carica papaya, pomegranate and even along with sunflower, cucurbitaceous vegetables, chili and lemon grass.

Insect pests such as scale insects and mealy bugs are detrimental for many plants [9]. Sandalwood is reported to infested by 23 species of coccids [7]. Striped mealy bug, Ferrisia virgata (Cockerell) is one of such pest which has potential to become a major threat to sandalwood plantation establishments in near future. Biological control of F. virgata using Australian lady bird beetle Cryptolaemus montrouzieri Mulsant (Coleoptera: Coccinellidae) is not new to India. In fact in New Delhi, biological control of $F$. virgata on tobacco using adults of $C$. montrouzieri was done successfully. F. virgata infestation on custard apple was also suppressed by using same agent [10]. Even in Citrus grandis [11] and Polyanthes tuberose [10] Psidium guajava $[12,13]$ biological control of $F$. virgata was achieved by releasing C. montrouzieri in field condition. Aim of the present study is to assess the population dynamics of F. virgata in Bangalore sandalwood provenance and biological control the same using C. montrouzieri.

Table 1: Flora composition of Bangalore sandal provenance.

\begin{tabular}{|c|c|c|c|c|c|c|c|}
\hline Sl. No & Plant species & Family & Type of Flora & Density & Frequency & Abundance & $\mathrm{A} / \mathrm{F}$ ratio \\
\hline 1 & Santalum album L. & Santalaceae & $\mathrm{T}$ & 18 & 1 & 18 & 18 \\
\hline 2 & Casurina equisitifolia Forster \& Forster.f. & Casurinaceae & $\mathrm{T}$ & 8 & 0.8 & 8 & 12.5 \\
\hline 3 & Bambusa sp & Poaceae & $\mathrm{T}$ & 0.2 & 0.2 & 1 & 5 \\
\hline 4 & Spathodea companulata Beauv. & Bignoniaceae & $\mathrm{T}$ & 0.6 & 0.4 & 1.5 & 3.75 \\
\hline 5 & Delonix regia R. Hook. & Leguminaceae & $\mathrm{T}$ & 2 & 0.6 & 3.33 & 5.55 \\
\hline 6 & Broussenetia papyrifera Vent. & Moraceae & $\mathrm{S}$ & 4 & 0.6 & 3.33 & 5.55 \\
\hline 7 & Ficus glomerata Roxb. & Moraceae & $\mathrm{T}$ & 0.2 & 0.2 & 1 & 5 \\
\hline 8 & Artocarpus heterophyllus Lam. & Moraceae & $\mathrm{T}$ & 0.4 & 0.2 & 1 & 5 \\
\hline 9 & Grevellia robusta A.Cunn. ex & Protreaceae & $\mathrm{T}$ & 0.2 & 0.2 & 1 & 5 \\
\hline 10 & Pongamia pinnata (L.) & Papilionaceae & $\mathrm{T}$ & 1.2 & 0.4 & 3 & 7.5 \\
\hline 11 & Leucaena leucocephala (Lam.) & Leguminosae & $\mathrm{T}$ & 0.6 & 0.2 & 3 & 15 \\
\hline 12 & Caryota urens L. & Palmae & S & 0.4 & 0.4 & 1 & 7 \\
\hline 13 & Lantana camara L. & Verbenaceae & S & 0.4 & 0.2 & 2 & 10 \\
\hline 14 & Ziziphus oenoplea (L.) Mil. & Rhamnaceae & S & 1 & 0.2 & 5 & 25 \\
\hline 15 & Gliricidia sepium (Jacq.) Kanthex. & Papilionaceae & S & 1.4 & 0.6 & 2.33 & 3.88 \\
\hline 16 & Coffea robusta $\mathrm{L}$. & Rubiaceae & $\mathrm{S}$ & 0.2 & 0.2 & 1 & 5 \\
\hline 17 & Coffea arabica L. & Rubiaceae & $\mathrm{S}$ & 2.2 & 0.4 & 5.5 & 13.75 \\
\hline 18 & Eucalyptus sp. & Myrtaceae & $\mathrm{T}$ & 0.2 & 0.2 & 1 & 5 \\
\hline 19 & Ziziphus sp. & Rhamnaceae & $\mathrm{T}$ & 1.6 & 0.4 & 4 & 10 \\
\hline 20 & Tamarindus indica L. & Caesalpiniaceae & $\mathrm{T}$ & 0.2 & 0.2 & 1 & 5 \\
\hline 21 & Annona squamosa L. & Annonaceae & $\mathrm{T}$ & 0.4 & 0.4 & 1 & 2.5 \\
\hline
\end{tabular}




\section{Material and Method}

Population dynamics of F virgata was conducted from January to July in both consecutive year 2012 and 2013 in sandalwood provenance of Institute of Wood Science \& Technology, Bangalore located at measurement of $12^{\circ} 58^{\prime} \mathrm{N} 77^{\circ}$ $38^{\prime} \mathrm{E}$ with a altitude of $1000 \mathrm{~m}$ in south India. Area consists of red loamy soil with an acidic pH ranging from 6.3 to 6.5. Semi arid area with annual precipitation is around $850 \mathrm{~mm}$ and means maximum and minimum temperatures ranging from $36.8{ }^{\circ} \mathrm{C}$ and $12.2{ }^{\circ} \mathrm{C}$ respectively. This sandalwood provinance is maintained naturally without any spraying/irrigation in one hectare of area and sandalwood in the provinance is associated with multiple floral diversity (Table 1). This particular provinance was the study area for the assessment of population dynamics of F.virgata. Five blocks of $17^{\circ} 17 \mathrm{~m}$ in the size were marked. Ten sandalwood trees of 3 to 4 years old were selected at random in each block. From these trees ten branches of size $30 \mathrm{~cm}$ in length were selected in each direction. On each branch, abundance of $F$. virgata was recorded. Observations were made at fortnight intervals. The data thus collected were pooled and mean was computed for statistical analysis. Meteorological data viz., monthly mean maximum and minimum temperatures, morning and evening relative humidity and total rainfall were also collected during the experimental period for statistical analysis. Correlation and multiple regression analysis were carried out separately for each factor by following the [14] method.

\section{Biological control Experiment}

Biological control experiment against $F$. virgata was done in the same sandalwood provinance. For this purpose total 20 trees infested with $F$. virgata were marked- ten trees for control, ten trees for release of coccinellids at the rate of $10 /$ tree. Pretreatment and post-treatment counts of $F$. virgata were assessed at random on ten twigs of $30 \mathrm{~cm}$ length, covering all the directions and top. Coccinellid C. montrouzieri was released in the selected trees which were highly infested. The release operation was done in February 2013. The observations were made at monthly intervals. The data thus collected were pooled and mean was computed for statistical analysis and the percentage reduction of infestation was calculated by Mulla's formula [15]:

$$
\text { (C1 x T2) }
$$

$\%$ Réduction = 100------------- x 100

( T1 X C2)

Where C1 = Level of infestation in Control Pretreatment

C2 = Level of infestation in Control Post treatment

T1 = Level of infestation in Treated Pretreatment

$\mathrm{T} 2$ = Level of infestation in Treated Post treatment

The study was conducted to determine the biological control potential of $C$. montrouzieri on F. virgata.
Results and Discussion

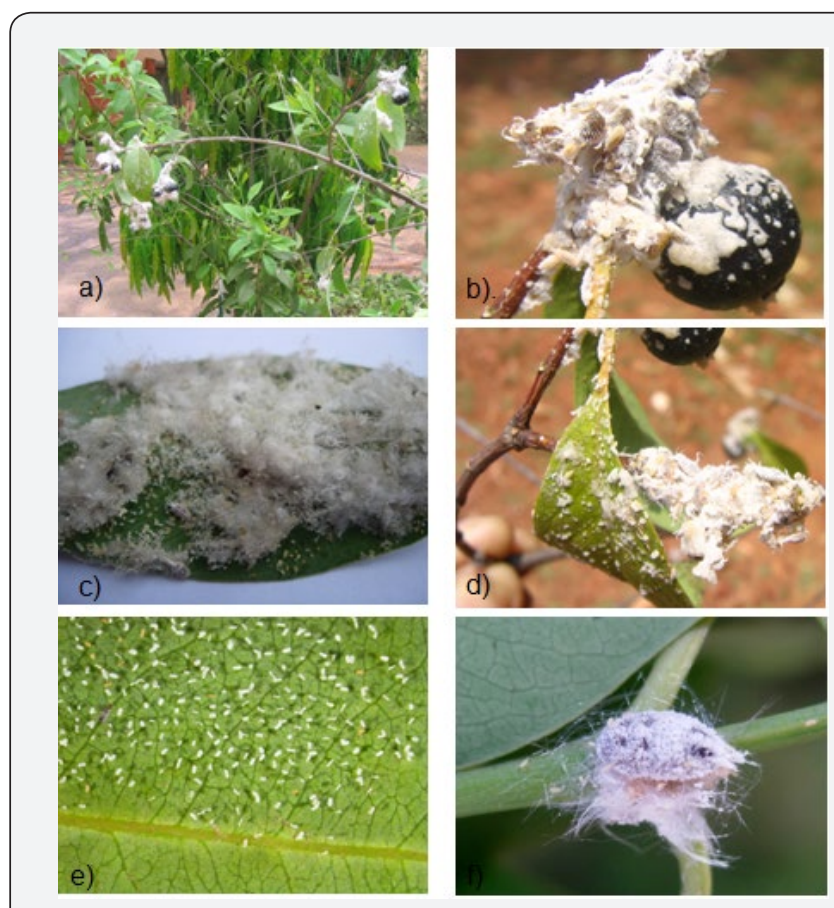

Figure 1: a) Ferrisia virgata infestation on sandalwood plant B) Sandal wood fruit c) Sandalwood leaf d) Sandalwood stem e) Eggs and nymphs of Ferrisia virgata f) Matured Ferrisia virgata female.

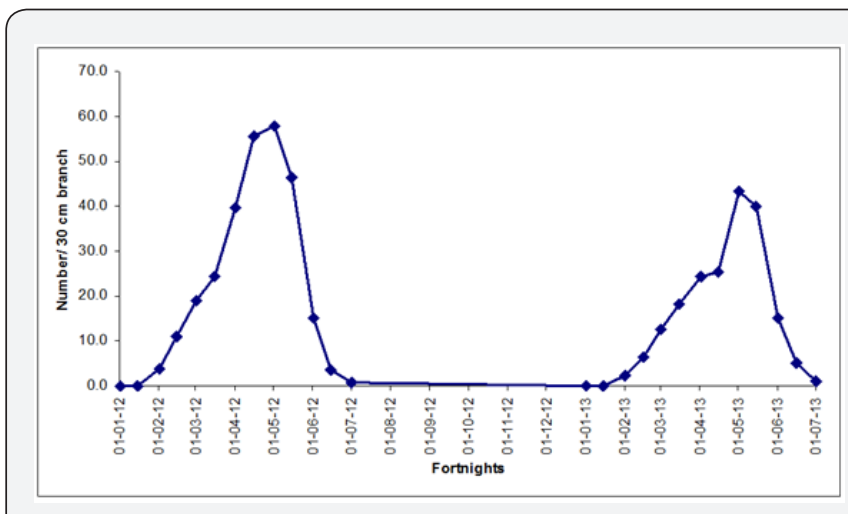

Figure 2: Population dynamics of Ferrisia virgata during 20122013.

F. virgata is a major coccid pest of sandalwood which was found to attacking various part of the tree including leaves, stems and fruits (Figure 1). Incidence of $F$. virgata was noticed at the beginning of January and gradually increased at its peak in between first fortnight of April to last fortnight of May (Figure 2) i.e. in dry season. Then the population slowly declines with the onset of monsoon and by August in proper monsoon period a small negligible population was left in field. Seasonality studies conducted at different locations on different host is also are in accordance with our results. In Java dry season's shows higher abundance of F. virgata [16] whereas in Philippines abundance was observed during February to May [17]. Profusion of F. virgata 
on Jute in Dacca was seen between July-August where as on garden land fruit infestation was found during winter and early spring [18]. In Egypt, F. virgata density on Acalypha macrophylla [19], Lantana camara [20], Dahlia pinnata [21] and Nerium oleander [22] showed two annual peaks; the first appeared in around July and the second in between September to October [23]. In Sri Lanka, F. virgata was found mostly in the dry zones [24]. Many Indian workers also reported that $F$. virgata reaches its peak at dry season and ceases activity mostly in winter and cooler months [25,26].

Table 2: Correlation and regression equation of the population of $F$ virgata with weather factors.

\begin{tabular}{|c|c|}
\hline Weather Factors & Correlation Coefficient \\
\hline Maximum temperature & 0.634 \\
\hline Minimum Temperature & 0.616 \\
\hline Maximum Relative Humidity & -0.233 \\
\hline Minimum Relative Humidity & -0.579 \\
\hline Rainfall & 0.383 \\
\hline Regression Equation & $\begin{array}{c}\text { Y= 25.30 +2.94 TMax+ 2.46 TMin } \\
-0.20 \mathrm{RHI}-0.126 \mathrm{RHII}-4.63 \mathrm{RF}\end{array}$ \\
\hline
\end{tabular}

Several environmental factors and weather parameters influences the population of $F$. virgata. Among weather parameters significant positive correlations (Table 2) were found with daily minimum temperature $(\mathrm{r}=+0.616, \mathrm{P}<0.05)$, and with daily maximum temperature $(\mathrm{r}=+0.634, \mathrm{P}<0.05)$. However, maximum relative humidity showed significant weak negative correlation $(\mathrm{r}=-0.233, \mathrm{P}<0.05)$ and minimum relative humidity showed significant strong negative correlation $(\mathrm{r}=-$ $0.579, \mathrm{P}<0.05)$. Rain fall showed moderate positive relationship $(\mathrm{r}=0.383, \mathrm{P}<0.05)$ with the population. As we mentioned earlier dry climate favors the population of $F$. virgata as its population was significantly correlated with temperature also mentions the same. Bangalore sandalwood provenance falls under semi arid condition hence forth both higher and lower temperature ranges falls under optimum temperature requirement of $F$. virgata that means, compliment the population growth without any setbacks. The most important factor is the atmospheric humidity which acts as limiting factor by favoring parasitic fungi [27] however [19] did not find any significant relation between population density and relative humidity.

The effect of release of $C$. montrouzieri was shown in Figure 3. The results revealed that release of $C$. montrouzieri at the rate 10 beetles per tree could control $F$. virgata within two months of release. The percentage reduction of $F$. virgata over control due to $C$. montrouzieri is also shown in Table 3. Our results on the biocontrol potency of $C$.montrouzieri against $F$. virgata agrees with the findings of $[28,29]$ that the decline in the $F$. virgata populations was attributed to the activity of the biotic agent $C$. montrouzieri.

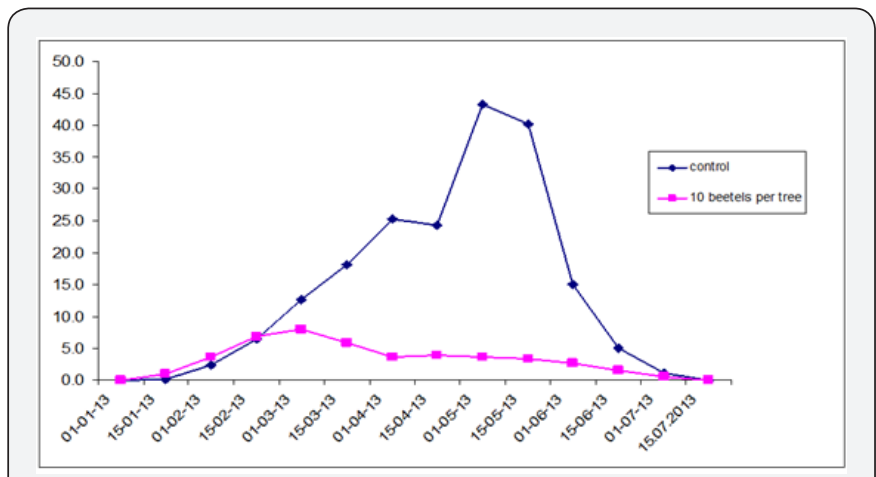

Figure 3: Effect of the release of C.montrouzieri adult beetles on the population of F.virgata on Indian sandalwood.

Table 3: Population of F. virgata and the effect of the release of C. montrouzieri adult beetles on Indian sandalwood Values in parenthesis are percentage reduction of $F$. virgata over control after the release of $C$. montrouzieri adult beetles.

\begin{tabular}{|c|c|c|c|c|c|c|c|c|c|c|c|c|c|}
\hline & 1 & 15 & 1 & 15 & 1 & 15 & 1 & 15-Apr & 1-May & 15 & 1 & 15-Jun & 1 \\
\hline & 13-Jan & 13-Jan & $13-\mathrm{Feb}$ & $13-\mathrm{Feb}$ & Mar & 13-Mar & Apr & 13 & 13 & May & Jun & 13 & 13-Jul \\
\hline & & & & & 13 & & 13 & & & 13 & 13 & & \\
\hline control & 0 & 0.1 & 2.4 & 6.5 & 12.6 & 18.1 & 24.3 & 25.3 & 43.3 & 40.1 & 15 & 5 & 1.1 \\
\hline \multirow[t]{2}{*}{$\begin{array}{l}10 \text { per } \\
\text { trees }\end{array}$} & & 1 & 3.71 & 6.9 & 7.99 & 5.84 & 3.37 & 3.95 & 3.69 & 3.4 & 2.74 & 1.49 & 0.53 \\
\hline & & & -78.82 & -71.11 & -64.93 & -68.28 & -66.34 & -28.86 & -3.05 & -11.24 & -70.97 & -93.45 & -99.08 \\
\hline
\end{tabular}

\section{Socio-economic consequences and need for biological control of sandalwood pest}

Agroforestry systems are fundamental features of the rural landscape of the Indian subcontinent. This system combines biophysical stability and socioeconomic adaptability which are critical for a vibrant and diversified agriculture that addresses both ecological and socioeconomic concerns. Yet these mixed species systems are increasingly being replaced by monocultures reversing the benefits of forestry into hazards as in case of eucalyptus and acacia in India. But sandalwood belonging to the Santalaceae family, a medium-sized evergreen hemi root parasitic tree needs host to support its development for nutrient intake and translocation and ensuring the agro forestry systems. In the early decades of twentieth century, typical monoculture 
approach of sandalwood tree farming lead to a complete failure and multiple species trails are emerged which not only promoted better sandalwood tree growth but also promised better yield and returns [30]. Experimental studies reveled that, tree species like Casuarina, Terminalia, Albizia, Dalbergia, and Pongamia support intimate haustorial associations with sandalwood roots and thus facilitates translocation of nutrient ions from the host to the hemiparasite [31]. More over in India sandalwood cultivation also supported the community farming at large extent.

Sandalwood is non shade tolerant tree species so host which can out grow it cannot be good host considering this farmers are growing the sandalwood in combination with Bamboo, mango, pomegranate, cashew, pineapple, spices and other local tree species considering that the host tree should start giving returns with minimum time period without hampering sandalwood growth [32]. That means wide virilities of sandalwood agro forestry practice are evolved with farmers conscious and general traditional ecological knowledge which has far fetching impact on the environmental and socioeconomic of the dependent farmer. At this point it is wise to remember that government relaxed the rule on sandalwood cultivation not only to increase the yield of it also has some social causes such as to help the small farmers to prosper under increasing globalization.

Farmers consider intercropping taking in mind the gestation period of the sandalwood yield. As per his opinion these annual yield crops returns will meet the farmer's present requirement and yield and returns obtained from long gestational period sandalwood is a bonus which he can use for major purposes and responsibilities such as marring off his daughter or their kids education [33]. Thus he is pinning his hopes as well as future on the future sandalwood return providing all necessary requirements for the crop. If this crop gets affected by insects the yield quality and product will be low leading into lower returns leading into compromised future for the farmer. But here comes the catch he cannot use convenient insecticides and pesticides for sandalwood pest control or other host tree insect/ pest control as market needs organic sandalwood without any compromise with quality. Especially for medical purpose sandalwood has to be grown without any chemical fertilizers and use of pesticides. As the plant is hemi parasitic and depends on host plant for water and nutrient intake there are chances that if host plants are treated with chemical insecticides the sandalwood may also get affected. Hence farmers are using biopesticides such as Neem (kernel, seeds \& leaves), Chitrakmool (Plumbago zeylanica), Datura, Cow's urine etc to prevent crop losses due to insect attack and diseases $[34,35]$. This ensure the environmental safety but many times it is observed that they failed to to control insect pests and as a result biological control programs are in great demand to ensure the need.

\section{Conclusion}

Increasing gap between demand and supply of sandalwood made the government relax its monopoly which otherwise existing to control the income generated under taxes. As a result large-scale sandalwood plantations for the commercial purpose with a rapid expansion are taking place. Sandalwood is a tree which will return commercial yield only after 15-20 years due to which plantations are coming up with other horticultural fruit species which will give annual or bi annual yields. F. virgata being a polyphagous pest species already established itself in most of these horticultural species. Earlier studies have revealed that $F$. virgata attacks the weak plants. Sandalwood being a semi parasitic in nature are naturally tend to be a weaker and destined to find severe attack by F. virgata in future [36]. In this context it can be concluded that application of these biological agents as lynchpin of sustainable pest management of Indian sandalwood [37].

\section{Acknowledgement}

The authors are grateful to Director, Coordinator (Research), Institute of Wood Science and Technology, Bangalore for providing facilities. Financial assistance (No.IWST/WBD/ $\mathrm{XI} / 118$ ) is provided by the Indian Council of Forestry Research and Education for conducting this research work.

\section{References}

1. Dhyani SK, Handa AK (2013) Agroforestry in India and its Potential for Ecosystem Services. In: Agroforestry Systems in India: Livelihood Security \& Ecosystem Services Advances in Agroforestry 10: 345-365.

2. Prasad R, Pandey DN, Kotwal PC (2000) Trees Outside Forests in India: A National Assessment, Indian Institute of Forest Management, Bhopal, India.

3. GOI (1999) National Forestry Action Programme, Government of India, Ministry of Environment and Forests, New Delhi, India, vol. 1 \& 2 .

4. HINDU (2008) Sell sandalwood trees without fear. The Hindu, India.

5. Kulkarni M (2011) Corporate sector enters sandalwood plantation. Business Standard (e-paper).

6. Arun KAN, Geetha J, Mohan RHY (2012) Sandalwood: history, uses, present status and the future. Current Science Association 103(12): $1408-1416$

7. Sundararaj R, Raja M (2011) Population dynamics of some coccids (Coccoidea: Hemiptera) infesting sandal (Santalum album Linn.) in Bangalore, India. Journal of Forestry Research 22(2):259- 262.

8. Venkatesha GVS, Patil KB, Anil KBH (2008) Natural sandalwood industry-Present scenario and future prospects. In: $\mathrm{S}$ Gairola, Rathore TS, Geeta J, Arun KAN, Pankaj Aggarwal (Eds.), Proceedings of the National seminar on "Conservation, Improvement, Cultivation and Management of Sandal (Santalum album L.). India: Brilliant Printers, Bangalore, India, pp. 196-203.

9. Ayyar TVR (1928) Contribution to our knowledge of south Indian Braconidae-Vipionidae. India Dept. of Agriculture MemoirsEntomological Series 10: 29-60.

10. Mani M, Krishnamoorthy A (2007) Field efficacy of Australian ladybird beetle Cryptolaemus montrouzieri in the suppression of mealybugs on custard apple. Indian Journal of Plant Protection 35(2): 217-219.

11. Mani M, Krishnamoorthy A (2008) Biological suppression of the mealybugs Planococcus citri (Risso), Ferrisia virgata (Cockerell) and Nipaecoccus viridis (Newstead) on pummelo with Cryptolaemus montrouzieri Mulsant in India. Journal of Biological Control 22(1): 169-172. 
12. Mani M, Krishnamoorthy A (1990) Natural suppression of mealybugs in guava orchards. Entomon 15(3-4): 245-247.

13. Mani M, Krishnamoorthy A (1997) Suppression of spherical mealybug, Nipaecoccus viridis (Newstead) (Homoptera: Pseudococcidae) on jack fruit. Entomon 22(2): 161-163.

14. Fisher RA, Yates F (1938) Statistical Tables for Biological, Agricultural and Medical Research. Oliver and Boyd, London, England.

15. Mulla MS, Norland L, Fanara DM, Darwazeh HA, Mckean DW (1971) Control of chironomid midges in recreational lakes. J Econ Entomol 64(1): 300-307.

16. Begemann H (1926) Report of the entomologist of the Coffee Berry Borer Fund for the period 3 December 1924-31 December 1925 Mededelingen van het Koffiebessenboeboek-Fonds No. 14: 194-207 Review of Applied Entomology (A) 14: 437.

17. Lapis EB (1970) The biology of the grey mealybug, Ferrisia virgata (Cockerell) (Pseudococcidae, Homoptera). Philippine Entomologist 1 (5): 397-405.

18. Das GM, Mukherjee TD, Gupta NS (1948) Biology of the common mealybug, Ferrisia virgata Ckll. (Coccidae), A pest on jute, Corchorus olitorius L., In Bengal. Proc. India. Indian Agricult 7: 112-117.

19. Ammar ED, Awadallah KT, Rashad A (1979) Ecological studies on Ferrisia virgata CKLL. on Acalypha shrubs in Dokki, Giza (Homoptera, Pseudococcidae). Deutsche Entomologische Zeitschrift 26(4-5): $207-$ 213.

20. Abd El-Said Ar (1997) Ecological and biological studies on mealybug parasitoids at Giza region. M.Sc. Thesis, Fac. Agric., Cairo University, Egypt.

21. Dawood MZ (1971) Survey of Aphids and Mealy-Bugs infesting ornamental Plants. - M. Sc. Thesis, Facul. Agric. Cairo University, Egypt, p.114.

22. El-Shazly MM (2006) Observations on oleander (Nerium oleander L., Apocynaceae) ecosystem in Giza, Egypt. Entomology Department, Faculty of Science, Cairo University, Giza, Egypt, Reports-icup 224.

23. Balboul OAH (2003) Ecological safe ways for controlling some insect pests attacking the guava trees at Giza Governorate. M.Sc. Thesis, Dept. Agric. Sci., Institute Environ. Studies and Res., Ain Shams University,Egypt, p.148.

24. Sirisena U, Watson GW, Hemachandra KS, Wijayagunasekara HNP (2013) Mealybugs (Hemiptera: Pseudococcidae) species on Economically Important Fruit Crops in Sri Lanka. Tropical Agricultural Research 25(1): 69-82.
25. Basu AC, Chatterjee PB (1963) Study on the behaviour and control of Ferrisia virgata (Ckll.)-a new mealy bug pest of betel vine, Piper betle Linn. in West Bengal, Zool. Soc. Bengal 1: 109-114.

26. Rawat RR, Modi BN (1969) Studies on biology of Ferrisia virgara (Ckll), (Pseudococcidae Homoptera) in Modhya Pradesh. Ind J Agric Sci 3: 274-281.

27. Betrem JE (1934) Witte Luis en Klimaat. (Mealybugs and Climate.)Bergcultures 8: 797-804.

28. Mani M, Krishnamoorthy A (2002) A Selectivity of different pesticides to citrus mealybug parasitoid Coccidoxinoides peregrina (Timberlake) Journal of Insect Science 15: 49-52.

29. Mani M, Krishnamoorthy A (2002) B Biological suppression of spherical mealybug Nipaecoccus viridis (Newstead) (Hemiptera, Pseudococcidae) on acid lime in India. Entomon 27: 423-424.

30. Viswanath S, Dhanya B, Rathore TS (2009) Domestication of Sandal (Santalum album L.) in India: constraints and prospects. APANews 34: 9-12.

31. Taide YB, Babu LC, Oommen A (1999) Comparative anatomy of haustoria formation of sandal on some hosts. Journal of Non-timber Forest Products 6(3-4): 179-182.

32. Mani M, Krishnamoorthy A, Singh SP (1990) Impact of the predator Cryptolaemus montrouzieri Mulsant on pesticide resistant populations of the striped mealybug, Ferrisia virgata (Ckll.) in guava in India. Insect Science and its application 11(2): 167-170.

33. Nayar R, Ananthapadmanabha HS, Venkatesh KR (1980) Seedling diseases of Sandal. Indian Journal of Forestry 3(1): 24-25.

34. Remadevi OK, Raja M, Ratna RA, Sivaramakrishnan VR, Santhakumaran LN (1997) Epidemic outbreak of lac insect, Kerria lacca (Kerr), on Santalum album (Sandal) and its control. Indian Forester 123(2): 143147.

35. Remadevi OK, SivaramakrishnanVR(1997) Indian wax scale, Ceroplastes cerifeurs (Fabricuius) Hemiptera: Coccidae), a potential pest of Santalum album L. Myforest 33(2): 469-471.

36. Sivaramakrishnan VR, Ananthapadmanabha HS, Ramanujam B, Subramanium M, Nayar R (1984) Control of seedlings diseases of sandal (Santalum album L.). J Indian Acad Wood Sci 15: 60-64.

37. Sivaramakrishnan VR, Nazarene HC, Rajamuthu K (1987) Poor Seed Setting in Sandal (Santalum album Linn). My forest, 23(2-4): 101-103.

\begin{tabular}{l} 
Your next submission with Juniper Publishers \\
will reach you the below assets \\
- Quality Editorial service \\
- Swift Peer Review \\
- Reprints availability \\
- E-prints Service \\
- Manuscript Podcast for convenient understanding \\
- Global attainment for your research \\
- Manuscript accessibility in different formats \\
( Pdf, E-pub, Full Text, Audio) \\
- Unceasing customer service \\
Track the below URL for one-step submission \\
https://juniperpublishers.com/online-submission.php \\
\hline
\end{tabular}

